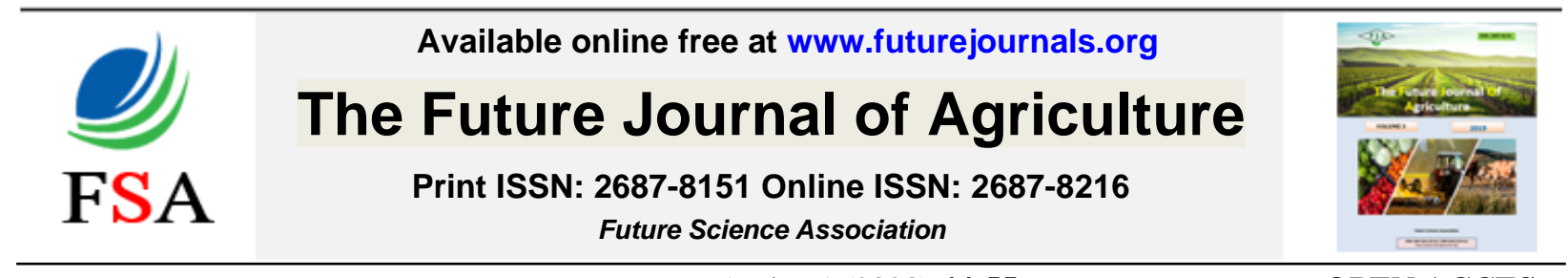

Future J. Agric., 1 (2020) 44-55

OPEN ACCES

DOI: 10.37229/fsa.fja.2020.01.23

\title{
EXTENDING THE KHALAL STAGE OF "ZAGHLOUL" DATES BY UTILIZING THE MODIFIED PACKING METHOD AND ANTI- ETHYLENE COMPOUNDS
}

\author{
Karim M. Farag'; Neven, M. N. Nagy' ${ }^{1}$ Naglaa, M. A. Yassin'² Amr, M. Haikal' ${ }^{1}$ and \\ Sobhy, S. Derhab ${ }^{2}$ \\ ${ }^{1}$ Department of Horticulture (Pomology), Faculty of Agriculture, Damanhour University, Egypt. \\ ${ }^{2}$ Horticulture Research Institute, Agriculture Research Center, Egypt.
}

*Corresponding author: sobhyderhab@hotmail.com Received: 25 Dec. 2019 ; Accepted: 23 Jan. 2020

\begin{abstract}
The present study was conducted in order to increase the availability of "Zaghloul" dates favored for consumption at the khalal stage. During the two successive seasons 2017 and 2018, dipping postharvest treatments and the modified packing method were applied to extend the khalal stage of "Zaghloul" date palm fruits. The treatments included the control (water), the control with wood shavings, $\mathrm{CaCl}_{2}(2 \%$, w/v), glycerol (1 $\%, \mathrm{v} / \mathrm{v}), \mathrm{CaCl}_{2}$ plus glycerol, AVG $(50 \mathrm{ppm})$, putrescine $(2 \mathrm{mM})$ and AVG followed by putrescine, then, the treated fruits with the substances treatments were embedded in layers of the wood shavings. All packed dates stored under cold storage conditions $\left(4^{\circ} \mathrm{C}\right.$ and $90-95 \%$ relative humidity). The results revealed that all treatments were able to reduce weight loss, fruit decay, electrolyte leakage, total soluble solids percentages and rutab score. More drastic reduction in these characteristics was found with the application of AVG when followed by putrescine in the presence of wood shavings. While, there was no clear trend for treatments effect on fruit total acidity content. Treated dates with $\mathrm{CaCl}_{2}$ or $\mathrm{AVG}$ when followed by putrescine had the highest values of total sugars. On the contrary, anthocyanin content in dates peel slightly increased by different treatments. This study provided evidence about the feasibility of using the combination of AVG with putrescine or $\mathrm{CaCl}_{2}$ plus glycerol in the presence of wood shavings to extend the khalal stage of "Zaghloul" dates and maintain their quality on a large scale.
\end{abstract}

Key words: date palm, khalal stage, AVG, putrescine, calcium solutions.

\section{INTRODUCTION}

The date palm fruits (Phoenix dactylifera L.) are highly demanded and consumed throughout the world, especially in the Middle East region. Egypt produces nearly 1.6 million tons per year (FAOSTAT, 2017). The development of date palm fruit is divided into five stages, namely hababouk, kimri, khalal (Bisr), rutab and tamr (Tamar) (AitOubahou and Yahia, 1999; Chao and Krueger, 2007; Zabar and Borowy, 2012). Color and texture have been considered the most important factor that determine date fruit quality especially those cultivars that could be consumed at the khalal stage such as "Zaghloul" and "Barhi". Fruits of these cultivars could be consumed at full coloration since the astringent taste disappears due to the polymerization of soluble tannins (Ait-Oubahou and Yahia, 1999; Zabar and Borowy, 2012). Unfortunately, few date clones, strains or cultivars are edible of this khalal stage especially in the gulf regions.

Moreover, dates are generally harvested by bunch which means that a huge amount of dates are harvested in a short time. Harvested fruits at the khalal stage may rapidly convert to the rutab stage and would be fermented within few days if not exposed to dehydration. Color intensity of khalal dates means greater nutritious value since "Zaghloul" dates are rich with the anthocyanin pigment which is very demanded antioxidants that are healthy and needed by date consumers (Farag, 2016). 
In many places, date producers and retailers have been obligated to sell their "Zaghloul" dates in low prices before they convert to the rutab stage. Thinking about the approach of early harvest cannot solve this problem since immature dates would not respond to artificial ripening by using ethylenereleasing compounds such as ethephon and may not be edible with low sugars content (Farag and Kassem, 1998).

Attempts to extend the khalal stage of dates and to prolong their shelf life have been focusing on using preharvest or postharvest treatments with calcium solutions (Hussein et al., 1993, a,b). However, date producer still lack a method or a producer that could be adopted on a large scale to prolong the khalal stage while reducing water loss to avoid fruit shriveling. Meanwhile, postharvest use of some surfactants such as Brij 30, Tween 20, Tween 80 or Triton $\mathrm{X}-100$ along with calcium proved to alter the fruit epicuticular wax which resulted in greater water loss and shriveling (Roy et al., 1996).

Fruits are mostly sold fresh during the season and still need enough storage facilities. Fruit price drops if they were harvested too early before full maturity and when they develop to the rutab stage. Even though "Zaghloul" dates are well known to the consumer, their postharvest loss is still high. Since it has been well established that dates are climacteric fruits (Serrano et al., 2001) which make them more sensitive to mishandling, mispacking and misstorage. Thus, the problem of short khalal stage and the need for packaging system that is affordable and effective must be tackled to provide consumers with solutions that could be adopted.

The antiethylene compound, namely AVG (aminoethoxyvinylglycine) has not been utilized well on a large scale (Mitcham et al., 1998, Clayton et al., 2000) as well as putrescine as a natural and safe compound that delays fruit aging and senescence (Bregoli et al., 2002; Tavakoli and Rahemi, 2014).

Wood shavings are available waste, inert material that could be utilized to load with the treatment solution and resemble a barrier against water loss from cold-stored fruits (Farag and AlMasri, 1999).

Thus, the objectives of this research was to provide the date grower with an affordable treatments that could be adopted on a large scale and to utilize an economic system to benefit from a waste material that is available to all date producers.

\section{MATERIALS AND MOTHODS}

During the 2017 and 2018 seasons, visually full Khalal (Bisr) dates (full red colored fruit) of the "Zaghloul" cultivar were collected from uniform group of "Zaghloul" date palm trees, from a commercial farm, Beheira government, Egypt. Dates were uniform and free from any disorders, defects and apparent pathogen infection as possible. Strands were separated from five bunches, mixed and randomly divided into 8 groups (treatments), each group contained 20 strands (5 strands/ each replicate). Any fruit with a degree of rutab development was discarded. Strands with attached fruits were washed in tap water, surface sterilized in sodium hypochlorite $(0.5 \% \mathrm{v} / \mathrm{v})$ for three minutes, then washed again in distilled water and left for air drying.

Fruits were treated by dipping in treatment solutions for five minutes then air dried, Treatments included:

1- Water as control without wood shavings.

2- Water with wood shavings.

3- Glycerol at $1 \%(\mathrm{v} / \mathrm{v})$.

4- Calcium chloride at $2 \%(\mathrm{w} / \mathrm{v})$.

5- Calcium chloride at $2 \%(\mathrm{w} / \mathrm{v})$ plus glycerol at $1 \%(\mathrm{v} / \mathrm{v})$.

6- AVG (aminoethoxyvinylglycine) at 50 ppm.

7- Putrescine at $2 \mathrm{mM}$.

8- AVG at $50 \mathrm{ppm}$ followed by putrescine at 2 $\mathrm{mM}$.

The used system in this study was developed by Farag and Al-Masri (1999), where a layer of wood shavings (small flakes) was at the bottom and the top of the treated strands (about $2 \mathrm{~cm}$ thick). Used wood shavings were wetted with the same treatment solution that has been used to treat fruits to prolong the uptake of solutions and to reduce exposure to the cold air in the cold chamber. Wood shavings treatment meant treating them with water only.

The system was set up in thick carton boxes lined with plastic sheets and was provided with side holes for ventilation. Boxes were left for 2 days at room temperature for drying $\left(22 \pm 2^{\circ} \mathrm{C}\right)$, then stored at $4^{\circ} \mathrm{C}$ and $90-95 \%$ relative humidity for 60 days in a cold chamber. The fruit quality characteristics of the experimental dates were measured three times as follows: 
1- Before treatments as initial data (zero time).

2- At the middle of cold storage period after (30 days).

3- At the end of cold storage period after (60 days).

Physical and chemical characteristics of fruits during storage were estimated as follows:

\section{Physical characteristics}

1- Weight loss (\%) was determined by weighing fruits and the loss in mass weight was recorded for each replicate. Data were calculated as percentage from the initial weight using the following equation:

$\begin{gathered}\text { Fruit weight loss } \\ (\%)\end{gathered}=\frac{\begin{array}{c}\text { Initial weight }- \text { Weight at } \\ \text { specific interval }\end{array}}{\text { Initial weight }} \times 100$

2- Decay percentage (\%) was evaluated by skin appearance, shriveling, chilling injury symptoms, and pathogenic rots. In every inspection, decayed fruits were discarded and the weight of fruits per replicate was used to express decay percentage utilizing the following equation according to ElSharony et al. (2015)

$$
\underset{(\%)}{\text { Decay percentage }}=\frac{\text { Weight of decayed fruits }}{\text { Initial weight }} \times 100
$$

3- Rutab score was estimated for each replicate individually according to an established score by Farag (1998) as follow:

(No rutab $=1 ; 0: 25 \%$ rutab $=2 ; 25: 50 \%$ rutab $=3 ; 50: 75 \%$ rutab $=4 ; 75: 100 \%$ rutab $=5$ ).

\section{Chemical characteristics}

1- Electrical conductivity (EC) of the flesh tissue was measured by using a conductivity meter. The ratio of $\mathrm{EC}$ was calculated by taking the electrolyte leakage of the flesh tissue before killing, then killing the tissue by deep freezing and taking another measurement after killing (to represent the total leakage of electrolytes). Each fruit was cut into two halves, and then each half was cut into four pieces. Two pieces were randomly taken from each fruit pieces to give 12 pieces for each replication to measure the EC 'as mentioned above.

2- Total soluble solids percentage (TSS \%) was determined in date palm fruit juice using a digital refractometer.
3- Total Acidity (TA) was estimated as g malic acid $/ 100 \mathrm{ml}$ juice according to the method described by A.O.A.C. (1995).

4- Total sugars percentages were evaluated by taking $5 \mathrm{~g}$ from the whole fruit (peel + pulp) and were extracted in $95 \%$ ethyl alcohol and total and reducing sugars were determined as percentage of fresh weight according to A.O.A.C. (1995).

5- Anthocyanin in "Zaghloul" dates content in 1 $\mathrm{g}$ fruit peel tissue was measured by Spectrophotometer at $535 \mathrm{~nm}$ according to the procedure of Fuleki and Francis (1968).

\section{Statistical analysis}

The data of this study was laid out as split plot analysis in a completely randomized design (CRD) where eight dipping applications represented the main plot and the storage durations were devoted as the sub plot. The analysis was done by using Costat program version 6.4 (Costat, 2008). The means were compared according to the least significant difference (LSD) at 0.05 level.

\section{RESULTS AND DISCUSSION}

The effect of postharvest applied treatments, cold storage time factor and their interaction on fruit physical characteristics of "Zaghloul" date palm

\section{1- Weight loss percentage}

The response of "Zaghloul" dates to postharvest applications of various treatments in addition to the effect of the storage time factor and their interactions were reported in Table 1 . The data revealed that there were many significant differences in weight loss in both seasons. Even the control fruits in the presence of wood shavings had significantly lower weight loss than that of the control in both seasons. Meanwhile, all applied treatments had a significant influence by reducing weight loss relative to the control whether with or without wood shavings. Moreover, many treatments were equally effective on reducing weight loss especially in both seasons. Furthermore, the lowest magnitude of weight loss was obtained with the treatment of "Zaghloul" dates with anti-ethylene compound AVG followed by putrescine with wood shavings in both seasons.

Thus, many natural treatments were able to reduce weight loss after harvest such as glycerol, calcium chloride or their combination in addition to AVG, putrescine and their combination too. 
The time factor also indicated to significant increase in weight loss, regardless the used treatment as the cold storage duration increased and monitored after 30 and 60 days in both seasons.

When the interaction between the used treatments and the time factor was followed, there were many obvious trends such as the highest weight loss in the control fruits after 60 days whether in the absence or presence of wood shavings in both seasons. Meanwhile, the least magnitude of water loss was found with the combination of calcium chloride and glycerol in both seasons after 30 days in the first season and with AVG followed by putrescine after 30 days in the second season.

Weight loss is attributed to losing of water during physiological processes. In addition, moisture loss and gaseous exchange from fruits is usually affected by the epidermal layers.

\section{2- Rutab score}

The development of the rutab stage as the storage duration passed was reported in Table 2 . The data indicated that such development in "Zaghloul" dates was significantly influenced by the treatments, regardless the time factor. Even in the control that was covered with wood shavings, the rutab score was significantly lower than that of the control without wood shavings. Moreover, many applied treatments resulted in a significant reduction of the rutab development when compared with the two types of the control such as glycerol, $\mathrm{CaCl}_{2}$ and their mixtures, all in presence of their wood shavings in a consistent manner in both seasons. Furthermore, more drastic reduction in rutab development was found with each of the treatments that included AVG, putrescine, or their combination in the presence of wood shavings along with each of the three above treatments relative to the two controls. They even caused a significant reduction in rutab development greater than that found with glycerol or calcium chloride in the presence of wood shavings (Table 2). Meanwhile, the time factor revealed a significant progress towards the formation of rutab score in both seasons, irrespective of the used treatment.

The effect of the interaction between used treatments and the time factor was also reported in Table 2. The data revealed that after 30 days of cold storage, treated "Zaghloul" dates with either AVG or AVG plus putresine along with the presence of wood shavings resulted in the lowest rutab score as compared with other treatments. On the contrary, the open control (without wood shavings) had the highest rutab score after 30 and 60 days of cold storage followed by the second control (the wood shavings alone) after 60 days of cold storage.

\section{3- Fruit decay percentage}

The influence of various used treatments on the percentage of fruit decay of used "Zaghloul" dates, regardless the time factor was reported in Table 3. The data indicated that the greatest decay was found with the two controls whether in the absence or in the presence of wood shavings in both seasons. In contrast, the least percentage of fruit decay was found with putrescine alone or along with AVG in the presence of wood shavings in a consistent manner in both seasons. However, some other treatments were also effective on reducing fruit decay such as glycerol, $\mathrm{CaCl}_{2}$ or their combination especially in the first season in the presence of wood shavings. The application of the anti-ethylene compound, namely AVG was also effective on reducing fruit decay in the second season as compared with the two controls but to a lesser magnitude than that obtained in the first season.

With regard to the effect of the time factor on the percentage of fruit decay, regardless the used treatment, the data in Table 3 also showed that as the storage duration was prolonged, there was a significant increase in the percentage of fruit decay in a consistent manner in both seasons.

Moreover, the interaction between both the treatments and the time factor revealed that the greatest decay magnitude was obtained with the control without wood shavings after 60 days of cold storage in both seasons. However, the control with wood shavings had less fruit decay than the control without shavings whether after 30 or 60 days of cold storage especially in the first season. Moreover, the least magnitude of fruit decay was obtained with fruit storage for 30 days of cold storage following specific treatments such as AVG plus putrescine, putrescine alone followed by AVG alone in both seasons in the presence of wood shavings.

The general trend of fruit decay percentage was found with all treatments with extension of the cold storage from 30 days to 60 days. Calcium treatment with the presence of wood shavings was also effective on reducing fruit decay especially after 30 days of cold storage. 
Table 1. Effect of postharvest applied treatments, cold storage time factor and their interaction on percentage of weight loss of "Zaghloul" dates during 2017 and 2018 seasons

\begin{tabular}{|c|c|c|c|c|c|c|c|c|}
\hline \multirow{3}{*}{ Treatments $(\mathbf{T})^{*}$} & \multicolumn{8}{|c|}{ Storage Periods Days (D) } \\
\hline & \multicolumn{4}{|c|}{ Season 2017} & \multicolumn{4}{|c|}{ Season 2018} \\
\hline & $\mathbf{0}$ & 30 & $60 * *$ & $\begin{array}{c}\text { Means } \\
(\mathrm{T})\end{array}$ & $\mathbf{0}$ & 30 & 60 & $\begin{array}{l}\text { Means } \\
(\mathrm{T})\end{array}$ \\
\hline Control & 0.001 & $9.93 \mathrm{~b}$ & $16.32 \mathrm{a}$ & $8.75 \mathrm{a}$ & $0.00 \mathrm{k}$ & $\begin{array}{c}5.99 \\
\text { def }\end{array}$ & $9.81 \mathrm{a}$ & $5.26 \mathrm{a}$ \\
\hline Control with Wood Shavings & 0.001 & $5.11 \mathrm{~g}$ & $9.49 \mathrm{c}$ & $4.86 \mathrm{~b}$ & $0.00 \mathrm{k}$ & $5.71 \mathrm{f}$ & $9.62 \mathrm{a}$ & $5.11 \mathrm{~b}$ \\
\hline $\begin{array}{l}\text { Glycerol with Wood } \\
\text { Shavings }\end{array}$ & 0.001 & $4.14 \mathrm{~h}$ & $6.18 \mathrm{f}$ & $3.44 \mathrm{de}$ & $0.00 \mathrm{k}$ & $3.61 \mathrm{hi}$ & 5.81 ef & $3.14 \mathrm{e}$ \\
\hline $\mathrm{CaCl}_{2}$ with Wood Shavings & 0.001 & $4.08 \mathrm{hi}$ & $6.76 \mathrm{e}$ & $3.61 \mathrm{~cd}$ & $0.00 \mathrm{k}$ & $4.14 \mathrm{~g}$ & $6.21 \mathrm{~d}$ & $3.45 \mathrm{~cd}$ \\
\hline $\begin{array}{l}\mathrm{CaCl}_{2}+\text { Glycerol with Wood } \\
\text { Shavings }\end{array}$ & 0.001 & $3.19 \mathrm{k}$ & $6.84 \mathrm{e}$ & $3.34 \mathrm{de}$ & $0.00 \mathrm{k}$ & $4.18 \mathrm{~g}$ & $6.60 \mathrm{c}$ & $3.59 \mathrm{c}$ \\
\hline AVG with Wood Shavings & 0.001 & $4.14 \mathrm{~h}$ & $7.53 \mathrm{~d}$ & $3.89 \mathrm{c}$ & $0.00 \mathrm{k}$ & $3.44 \mathrm{ij}$ & $7.02 \mathrm{~b}$ & $3.49 \mathrm{c}$ \\
\hline $\begin{array}{l}\text { Putrescine with Wood } \\
\text { Shavings }\end{array}$ & 0.001 & $3.76 \mathrm{j}$ & $6.23 \mathrm{f}$ & $3.33 \mathrm{de}$ & $0.00 \mathrm{k}$ & $3.86 \mathrm{gh}$ & $6.10 \mathrm{de}$ & $3.32 \mathrm{~d}$ \\
\hline $\begin{array}{l}\text { AVG followed by Putrescine } \\
\text { with Wood Shavings }\end{array}$ & 0.001 & $3.82 \mathrm{ij}$ & $6.10 \mathrm{f}$ & $3.30 \mathrm{e}$ & $0.00 \mathrm{k}$ & $3.25 \mathrm{j}$ & $\begin{array}{c}5.90 \\
\text { def }\end{array}$ & $3.05 \mathrm{e}$ \\
\hline Means (D) & $0.00 \mathrm{c}$ & $4.77 \mathrm{~b}$ & $8.18 \mathrm{a}$ & & $0.00 \mathrm{c}$ & $4.27 \mathrm{~b}$ & $7.13 \mathrm{a}$ & \\
\hline
\end{tabular}

* Values within a column, with similar letters were not significantly different according to the Least Significant Difference (LSD) at 0.05 level.

** Values under the time factor $(0,30,60$ days) with similar letters according to the Least Significant Difference (LSD) at 0.05 level were not significantly different.

Table 2. Effect of postharvest applied treatments, cold storage time factor and their interaction on rutab score of "Zaghloul" dates during 2017 and 2018 seasons

\begin{tabular}{|c|c|c|c|c|c|c|c|c|}
\hline \multirow{3}{*}{ Treatments $(\mathbf{T})^{*}$} & \multicolumn{8}{|c|}{ Storage Periods Days (D) } \\
\hline & \multicolumn{4}{|c|}{ Season 2017} & \multicolumn{4}{|c|}{ Season 2018} \\
\hline & $\mathbf{0}$ & 30 & $60 * *$ & $\begin{array}{c}\text { Means } \\
(\mathrm{T})\end{array}$ & $\mathbf{0}$ & 30 & 60 & $\begin{array}{c}\text { Means } \\
(\mathbf{T}) \\
\end{array}$ \\
\hline Control & $0.00 \mathrm{j}$ & $3.20 \mathrm{~b}$ & $4.20 \mathrm{a}$ & $2.47 \mathrm{a}$ & $0.00 \mathrm{i}$ & $3.05 \mathrm{~b}$ & $3.85 \mathrm{a}$ & $2.30 \mathrm{a}$ \\
\hline Control with Wood Shavings & $0.00 \mathrm{j}$ & $2.59 \mathrm{~cd}$ & $3.13 \mathrm{~b}$ & $1.90 \mathrm{~b}$ & $0.00 \mathrm{i}$ & $2.10 \mathrm{de}$ & $3.09 \mathrm{~b}$ & $1.73 \mathrm{~b}$ \\
\hline $\begin{array}{l}\text { Glycerol with Wood } \\
\text { Shavings }\end{array}$ & $0.00 \mathrm{j}$ & $2.13 \mathrm{~g}$ & $2.60 \mathrm{c}$ & $1.57 \mathrm{c}$ & $0.00 \mathrm{i}$ & $2.12 \mathrm{de}$ & $2.59 \mathrm{c}$ & $1.57 \mathrm{~cd}$ \\
\hline $\mathrm{CaCl}_{2}$ with Wood Shavings & $0.00 \mathrm{j}$ & $1.84 \mathrm{~h}$ & $2.48 \mathrm{de}$ & $1.44 \mathrm{~d}$ & $0.00 \mathrm{i}$ & $1.92 \mathrm{f}$ & $2.52 \mathrm{c}$ & $1.48 \mathrm{~cd}$ \\
\hline $\begin{array}{l}\mathrm{CaCl}_{2}+\text { Glycerol with Wood } \\
\text { Shavings }\end{array}$ & $0.00 \mathrm{j}$ & $2.15 \mathrm{~g}$ & $2.70 \mathrm{c}$ & $1.57 \mathrm{c}$ & $0.00 \mathrm{i}$ & $2.26 \mathrm{~d}$ & $2.60 \mathrm{c}$ & $1.62 \mathrm{c}$ \\
\hline AVG with Wood Shavings & $0.00 \mathrm{j}$ & $1.73 \mathrm{hi}$ & $2.32 \mathrm{f}$ & $1.35 \mathrm{e}$ & $0.00 \mathrm{i}$ & $1.63 \mathrm{gh}$ & $2.06 \mathrm{ef}$ & $1.23 \mathrm{e}$ \\
\hline $\begin{array}{l}\text { Putrescine with Wood } \\
\text { Shavings }\end{array}$ & $0.00 \mathrm{j}$ & $1.72 \mathrm{i}$ & $2.40 \mathrm{ef}$ & $1.35 \mathrm{e}$ & $0.00 \mathrm{i}$ & $1.75 \mathrm{~g}$ & $2.05 \mathrm{ef}$ & $1.26 \mathrm{e}$ \\
\hline $\begin{array}{l}\text { AVG followed by Putrescine } \\
\text { with Wood Shavings }\end{array}$ & $0.00 \mathrm{j}$ & $1.70 \mathrm{i}$ & $2.40 \mathrm{ef}$ & $1.36 \mathrm{de}$ & $0.00 \mathrm{i}$ & $1.50 \mathrm{~h}$ & 2.00 ef & $1.16 \mathrm{e}$ \\
\hline Means (D) & $0.00 \mathrm{c}$ & $2.13 \mathrm{~b}$ & $2.78 \mathrm{a}$ & & $0.00 \mathrm{c}$ & $2.04 \mathrm{~b}$ & $2.59 \mathrm{a}$ & \\
\hline
\end{tabular}

* Values within a column, with similar letters were not significantly different according to the Least Significant Difference (LSD) at 0.05 level.

** Values under the time factor (0, 30, 60 days) with similar letters according to the Least Significant Difference (LSD) at 0.05 level were not significantly different. 
Table 3. Effect of postharvest applied treatments, cold storage time factor and their interaction on percentage of decay of "Zaghloul" dates during 2017 and 2018 seasons

\begin{tabular}{|c|c|c|c|c|c|c|c|c|}
\hline \multirow{3}{*}{ Treatments $(\mathbf{T})^{*}$} & \multicolumn{8}{|c|}{ Storage Periods Days (D) } \\
\hline & \multicolumn{4}{|c|}{ Season 2017} & \multicolumn{4}{|c|}{ Season 2018} \\
\hline & $\mathbf{0}$ & 30 & $60 * *$ & $\begin{array}{l}\text { Means } \\
\text { (T) }\end{array}$ & $\mathbf{0}$ & 30 & 60 & $\begin{array}{l}\text { Means } \\
(\mathrm{T})\end{array}$ \\
\hline Control & 0.001 & $9.18 \mathrm{e}$ & $13.76 \mathrm{a}$ & $7.64 \mathrm{a}$ & $0.00 \mathrm{k}$ & $7.20 \mathrm{f}$ & $14.82 \mathrm{a}$ & $7.34 \mathrm{a}$ \\
\hline Control with Wood Shavings & 0.001 & $7.77 \mathrm{~h}$ & $10.48 \mathrm{c}$ & $6.08 \mathrm{~b}$ & $0.00 \mathrm{k}$ & $\begin{array}{c}7.50 \\
\text { def }\end{array}$ & $10.50 \mathrm{~b}$ & $6.00 \mathrm{~b}$ \\
\hline $\begin{array}{l}\text { Glycerol with } \text { Wood } \\
\text { Shavings }\end{array}$ & 0.001 & $6.46 \mathrm{i}$ & $10.87 \mathrm{~b}$ & $5.78 \mathrm{c}$ & $0.00 \mathrm{k}$ & $7.25 \mathrm{ef}$ & $10.82 \mathrm{~b}$ & $6.02 \mathrm{~b}$ \\
\hline $\mathrm{CaCl}_{2}$ with Wood Shavings & 0.001 & $6.25 \mathrm{i}$ & $8.47 \mathrm{~g}$ & $4.90 \mathrm{~d}$ & $0.00 \mathrm{k}$ & $5.75 \mathrm{~h}$ & $7.80 \mathrm{~d}$ & $4.51 \mathrm{~d}$ \\
\hline $\begin{array}{l}\mathrm{CaCl}_{2}+\text { Glycerol with Wood } \\
\text { Shavings }\end{array}$ & 0.001 & $7.80 \mathrm{~h}$ & $9.58 \mathrm{~d}$ & $5.79 \mathrm{c}$ & $0.00 \mathrm{k}$ & $6.50 \mathrm{~g}$ & $8.40 \mathrm{c}$ & $4.96 \mathrm{c}$ \\
\hline AVG with Wood Shavings & 0.001 & $4.52 \mathrm{j}$ & 8.98 ef & $4.50 \mathrm{e}$ & $0.00 \mathrm{k}$ & $5.05 \mathrm{i}$ & $8.67 \mathrm{c}$ & $4.57 \mathrm{~d}$ \\
\hline $\begin{array}{l}\text { Putrescine with } \text { Wood } \\
\text { Shavings }\end{array}$ & 0.001 & $4.60 \mathrm{j}$ & $8.82 \mathrm{f}$ & $4.47 \mathrm{e}$ & $0.00 \mathrm{k}$ & $3.87 \mathrm{j}$ & $7.63 \mathrm{de}$ & $3.83 \mathrm{e}$ \\
\hline $\begin{array}{l}\text { AVG followed by Putrescine } \\
\text { with Wood Shavings }\end{array}$ & 0.001 & $4.21 \mathrm{k}$ & $8.55 \mathrm{~g}$ & $4.25 \mathrm{e}$ & $0.00 \mathrm{k}$ & $3.95 \mathrm{j}$ & $7.82 \mathrm{~d}$ & $3.92 \mathrm{e}$ \\
\hline Means (D) & $0.00 \mathrm{c}$ & $6.35 \mathrm{~b}$ & $9.94 \mathrm{a}$ & & $0.00 \mathrm{c}$ & $5.88 \mathrm{~b}$ & $9.56 \mathrm{a}$ & \\
\hline
\end{tabular}

* Values within a column, with similar letters were not significantly different according to the Least Significant Difference (LSD) at 0.05 level.

** Values under the time factor $(0,30,60$ days) with similar letters according to the Least Significant Difference (LSD) at 0.05 level were not significantly different.

The effect of postharvest applied treatments, cold storage time factor and their interaction on fruit chemical characteristics of "Zaghloul" date palm

\section{1- Electrolyte Leakage}

The effect of various used treatments, regardless time factor, on the percentage of electrolyte leakage of date fruits as an indicator to the health or the integrity of the plasma membrane was reported in Table 4. The data revealed that all treatments were able to significantly reduce the values of electrolyte leakage as compared with the control. Even the control with wood shavings had less leakage of electrolytes than that found in the control without wood shavings in both seasons. The least magnitude of electrolyte leakage was found with AVG plus putrescine with wood shavings in both seasons followed by the treatment with putrescine in the presence of wood shavings. In addition, AVG with wood shavings resulted in a significant reduction in electrolyte leakage as compared with the two controls in both seasons. Thus, all used treatments resulted in a significant reduction of electrolyte leakage than the controls with variations in the magnitude of such reduction. Moreover, the time factor indicated to an increase in the values of electrolyte leakage as the storage period increased.
With regard to the effect of the interaction between the treatments and the time factor, the data indicated that $\mathrm{AVG}$ alone, putrescine alone or their combination in the presence of wood shavings resulted in the least leakage of electrolytes after 30 days of cold storage in a consistent manner in both seasons. Meanwhile, the greatest magnitude of electrolyte leakage was obtained with the control whether with or without the wood shavings after 60 days of cold storage. It was evident again that the treatments of glycerol, $\mathrm{CaCl}_{2}$, and their combination were also able to significantly reduce the values of electrolyte leakage after 30 or 60 days of cold storage along with the use of wood shavings in both seasons.

It was also reported that electrolyte leakage after cold storage is an excellent indicator of cell membrane integrity. Thus, more the damage, more the leakage of cell electrolytes. Furthermore, the reduction of electrolyte leakage in AVG -treated fruits could be due to its influence on maintaining the membrane integrity, which reflects on reducing the leakage of electrolytes.

\section{2- Total soluble solids (TSS)}

The effect of various applied treatments, regardless the time factor, on the total soluble solids 
(TSS) of "Zaghloul" fruit juice was reported in Table 5. The data showed a significant influence of using wood shavings to cover the fruits since the open control without wood shavings had significantly greater TSS than that of the covered one (with wood shavings). Moreover, AVG alone or along with putrescine through the presence of the wood shavings system resulted in a significant reduction in the TSS in addition to putrescine alone in both seasons. On the other hand, calcium chloride alone or plus glycerol were equally effective on the TSS value especially in the second season with a slight reduction in the first season caused by the combination of calcium chloride plus glycerol.

With regard to the time factor, the data in Table 5 also showed a significant increase in TSS values as the storage duration extended from 30 to 60 days in both seasons.

Furthermore, the interaction between the treatments and the time (Table 5) indicated that the lowest TSS values were obtained with all treatments at the zero time of the storage duration. On the contrary, the highest TSS values was found with the open control without wood shavings after 60 days of cold storage in both seasons. It was also obvious in both seasons that some treatments were able to reduce TSS after 30 days of cold storage in an equal magnitude especially in the first season, these treatments included $\mathrm{AVG}$, putrescine as well as AVG plus putrescine.

This trend could be attributed to the increase in water loss through the storage period and to the concentration of fruit juice as the fruits were exposed (no wood shavings around) which work as a barrier to water loss especially under chilling temperature.

\section{3- Acidity}

The effect of postharvest applied treatments on juice acidity in both seasons was reported in Table 6 . The data in this table showed that there was no clear trend for treatments effects on dates acidity contents. Whereas, the least values of acidity were found with the control in the absence of wood shavings in the first season or putrescine alone or along with AVG in the second one for "Zaghloul" dates.

The cold storage time factor assessment also proved the significant reduction in acidity content after 30 and 60 days of cold storage relative to the initial time in both seasons.
Meanwhile, the interaction between the treatments and the time factor illustrated in Table 6 showed that the greatest reduction in fruit acidity content was found with the open control without wood shavings after 60 days of cold storage in the first season, but in the second season, the applications of putrescine alone or when followed AVG treatment caused this result.

\section{4- Total sugars content}

Concerning the response of total sugars to postharvest applied treatments, the data in Table 7 showed that treated dates with putrescine alone in presence of wood shavings had the least total sugars content in both seasons. However, the applications of $\mathrm{CaCl}_{2}$ or $\mathrm{AVG}$ when followed by putrescine were able to increase the total sugars content of "Zaghloul" dates relative to the control in the second season. It was not the trend in the first season whereas, the embedded dates in wood shavings with $\mathrm{CaCl}_{2}$ had a similar content of sugars with untreated dates (the control without wood shavings).

With regard to the effect of the time factor on the total sugars content of dates, regardless the used treatment, the data in Table 7 also showed that as the storage duration was prolonged, there was a significant increase in the total sugars content in a consistent manner in both seasons.

The data in the same Table presented that when the treatment with calcium chloride interacted with duration after 60 days of cold storage, the greatest magnitude of total sugars was obtained in "Zaghloul" dates in the two seasons. Meanwhile, irrespective the initial time, the individual application of putrescine after 30 days caused the least values of sugars content for "Zaghloul" dates in both seasons.

\section{5- Anthocyanin content}

The changes in anthocyanin content of "Zaghloul" date palm fruit peel in response to postharvest applied treatments were reported in Table 8. It was obvious that all treatments significantly increased anthocyanin content in the dates peel relative to the control in both seasons. Furthermore, $\mathrm{CaCl}_{2}$ plus glycerol treatment had the highest effect to enhance anthocyanin content in the first season. On the other hand, the sole application of glycerol and the treatment with AVG when followed with putrescine were able to increase the content of anthocyanin for "Zaghloul" dates in the second season. 
As for the cold storage time factor, the data in Table 8 revealed a significant increase was occurred after 30 days of cold storage in anthocyanin content as compared with the initial time and the duration after 60 days in the first season. However, the durations after 30 and 60 days had equal effect in the second season.

Meanwhile, the interaction between postharvest applied treatments and the cold storage time factor in the same Table showed that the treatment with $\mathrm{CaCl}_{2}$ whether alone or combined with glycerol had the greatest values in anthocyanin content after 30 days of cold storage for "Zaghloul" dates in the first season. However, the treatment with AVG when followed with putrescine was capable of significantly enhancing anthocyanin content in dates peel after 60 days of cold storage in the second season.

There has been an increasing demand on the consumption of date fruits especially at the full khalal (Bisr) stage or full coloration fruits, at this stage, dates are more crispy with a strong flavor in addition to the higher content of glucose and fructose and less percentage of sucrose.

Dry dates are less demanded in the European or the American market since they consider the fruit is too hard. They sometimes recommend rehydrating dry dates of popular cultivars before their consumption.

In addition, the high content of anthocyanin pigments in "Zaghloul" dates add to the nutritious value of the khalal stage of this cultivar.

It was found that there is a possibility to extend the khalal stage of "Khesab" dates by modifying the packing system and modifying the used calcium formulation (Farag and Al-Masri, 1999) such modification tended to prolong the uptake of the treatment solution and to reduce air movement around fruits during cold storage since date strands were embedded between two layers of small pieces of wood shavings (saw dust flakes). These wood shavings created a physical barrier which reduced water loss in addition to utilizing them for further increase of the actual uptake of the treatment solution. The synergetic effect of calcium and glycerol on extending the khalal stage and reducing the leakage of electrolytes agreed with findings of Farag and Al-Masri (1999) who worked on "Khesab" dates.
Since it was reported that dates are climacteric fruits (Serrano et al., 2001), thus the development of dates from the khalal to the rutab stage (ripe fruits) is greatly influenced by ethylene content. Thus, the delay in the development of the rutab stage by anti-ethylene compound called AVG (aminoethoxyvinyl glycin) could be explained on the basis of the inhibitory effect or the biosynthesis of ethylene.

It was found that AVG inhibits the conversion of SAM (S-adenosyl methionine) to ACC (aminocyclopropane carboxylic acid) which in turn reduced the autocatalysis that results in further ethylene production (Mitcham et al., 1998, Clayton et al., 2000).

Similar trend of results was also obtained with the application of AVG plus putrescine or putrescine alone along with the use of wood shavings. Putrescine is one of the natural polyamines that delay tissue senescence or ripening and causes a deviation in the pathway of ethylene biosynthesis (Bregoli et al., 2002, Costa et al. 2003).

Thus, putrescine has been utilized to retard the loss of tissue integrity in many types of fruits (Farag, 1998) which reflected on preserving the tissue texture as one of the main desired properties of dates. Retarding fruit deterioration and enhancing the shelf life by calcium treatment was also supported by other studies (Omaima et al., 2011, Atia et al., 2018)

The presence of glycerol was helpful in extending the duration of tissue exposure to calcium since glycerol was reported to prolong the dryness time (Farag and Al-Masri, 1999, Farag et al., 2017).

It was also reported that electrolyte leakage after cold storage is an excellent indicator of cell membrane integrity. Thus, more the damage, more the leakage of cell electrolytes.

\section{CONCLUSION}

In conclusion, this study provided evidences about the possibility of extending the khalal stage of "Zaghloul" dates by safe treatments and by modifying the packing system using feasible means that could afforded by date producers. 
Table 4. Effect of postharvest applied treatments, cold storage time factor and their interaction on percentage of electrolyte leakage of "Zaghloul" dates during 2017 and 2018 seasons

\begin{tabular}{|c|c|c|c|c|c|c|c|c|}
\hline \multirow{3}{*}{ Treatments $(\mathbf{T})^{*}$} & \multicolumn{8}{|c|}{ Storage Periods Days (D) } \\
\hline & \multicolumn{4}{|c|}{ Season 2017} & \multicolumn{4}{|c|}{ Season 2018} \\
\hline & $\mathbf{0}$ & 30 & $60 * *$ & $\begin{array}{c}\text { Means } \\
(\mathbf{T})\end{array}$ & $\mathbf{0}$ & 30 & 60 & $\begin{array}{c}\text { Means } \\
(\mathbf{T})\end{array}$ \\
\hline Control & 0.001 & $18.33 \mathrm{c}$ & $21.64 \mathrm{a}$ & $13.32 \mathrm{a}$ & 0.001 & $\begin{array}{c}18.19 \\
\mathrm{~cd}\end{array}$ & $23.25 \mathrm{a}$ & $13.81 \mathrm{a}$ \\
\hline Control with Wood Shavings & 0.001 & $18.21 \mathrm{c}$ & $19.34 b$ & $12.52 \mathrm{~b}$ & 0.001 & $16.36 \mathrm{e}$ & $20.50 \mathrm{~b}$ & $12.28 \mathrm{~b}$ \\
\hline $\begin{array}{l}\text { Glycerol with } \quad \text { Wood } \\
\text { Shavings }\end{array}$ & 0.001 & $16.40 \mathrm{e}$ & $18.41 \mathrm{c}$ & $11.60 \mathrm{c}$ & 0.001 & $12.51 \mathrm{j}$ & $17.70 \mathrm{~d}$ & $10.07 \mathrm{c}$ \\
\hline $\mathrm{CaCl}_{2}$ with Wood Shavings & 0.001 & $16.06 \mathrm{f}$ & $18.18 \mathrm{c}$ & $11.41 \mathrm{~d}$ & 0.001 & $\begin{array}{l}12.63 \\
\mathrm{ij}\end{array}$ & $18.57 \mathrm{c}$ & $10.40 \mathrm{c}$ \\
\hline $\begin{array}{l}\mathrm{CaCl}_{2}+\text { Glycerol with Wood } \\
\text { Shavings }\end{array}$ & 0.001 & $\begin{array}{c}16.31 \\
\text { ef }\end{array}$ & $17.85 \mathrm{~d}$ & $11.39 \mathrm{~d}$ & 0.001 & $\begin{array}{c}13.13 \\
\text { hi }\end{array}$ & $\begin{array}{l}17.97 \\
\mathrm{~cd}\end{array}$ & $10.37 \mathrm{c}$ \\
\hline AVG with Wood Shavings & 0.001 & $10.20 \mathrm{j}$ & $11.82 \mathrm{~h}$ & $7.34 \mathrm{f}$ & 0.001 & $9.26 \mathrm{k}$ & $15.60 \mathrm{f}$ & $8.28 \mathrm{~d}$ \\
\hline $\begin{array}{l}\text { Putrescine with Wood } \\
\text { Shavings }\end{array}$ & 0.001 & $10.39 \mathrm{j}$ & $13.66 \mathrm{~g}$ & $8.02 \mathrm{e}$ & 0.001 & $8.92 \mathrm{k}$ & $\begin{array}{l}13.60 \\
\mathrm{gh}\end{array}$ & $7.50 \mathrm{e}$ \\
\hline $\begin{array}{l}\text { AVG followed by Putrescine } \\
\text { with Wood Shavings }\end{array}$ & 0.001 & $9.67 \mathrm{k}$ & $10.95 \mathrm{i}$ & $6.87 \mathrm{~g}$ & 0.001 & $8.88 \mathrm{k}$ & $13.80 \mathrm{~g}$ & $7.56 \mathrm{e}$ \\
\hline Means (D) & $0.00 \mathrm{c}$ & $14.45 \mathrm{~b}$ & $16.48 \mathrm{a}$ & & $0.00 \mathrm{c}$ & $12.49 \mathrm{~b}$ & $17.62 \mathrm{a}$ & \\
\hline
\end{tabular}

* Values within a column, with similar letters were not significantly different according to the Least Significant Difference (LSD) at 0.05 level.

** Values under the time factor $(0,30,60$ days) with similar letters according to the Least Significant Difference (LSD) at 0.05 level were not significantly different.

Table 5. Effect of postharvest applied treatments, cold storage time factor and their interaction on percentage of TSS of "Zaghloul" dates during 2017 and 2018 seasons

\begin{tabular}{|c|c|c|c|c|c|c|c|c|}
\hline \multirow{3}{*}{ Treatments $(\mathbf{T})^{*}$} & \multicolumn{8}{|c|}{ Storage Periods Days (D) } \\
\hline & \multicolumn{4}{|c|}{ Season 2017} & \multicolumn{4}{|c|}{ Season 2018} \\
\hline & $\mathbf{0}$ & 30 & $60 * *$ & $\begin{array}{l}\text { Means } \\
\text { (T) }\end{array}$ & $\mathbf{0}$ & 30 & 60 & $\begin{array}{l}\text { Means } \\
(\mathrm{T})\end{array}$ \\
\hline Control & $23.20 \mathrm{k}$ & $25.41 \mathrm{de}$ & $29.62 \mathrm{a}$ & $26.07 \mathrm{a}$ & $\begin{array}{l}24.10 \\
\text { gh }\end{array}$ & $26.38 \mathrm{c}$ & $30.30 \mathrm{a}$ & $\begin{array}{c}26.92 \\
\mathrm{a}\end{array}$ \\
\hline Control with Wood Shavings & $23.20 \mathrm{k}$ & $25.43 \mathrm{de}$ & $27.11 \mathrm{bc}$ & $25.24 \mathrm{~b}$ & $\begin{array}{l}24.10 \\
\text { gh }\end{array}$ & $\begin{array}{l}24.45 \\
\text { efg }\end{array}$ & $25.35 \mathrm{~d}$ & $\begin{array}{c}24.63 \\
\mathrm{~cd}\end{array}$ \\
\hline Glycerol with Wood Shavings & $23.20 \mathrm{k}$ & 25.03 ef & $26.89 \mathrm{c}$ & $25.04 \mathrm{~b}$ & $\begin{array}{l}24.10 \\
\text { gh }\end{array}$ & $\begin{array}{c}24.89 \\
\text { def }\end{array}$ & $\begin{array}{c}26.78 \\
\mathrm{bc}\end{array}$ & $\begin{array}{c}25.25 \\
\mathrm{bc}\end{array}$ \\
\hline $\mathrm{CaCl}_{2}$ with Wood Shavings & $23.20 \mathrm{k}$ & $24.06 \mathrm{hi}$ & $27.49 \mathrm{~b}$ & $24.91 \mathrm{~b}$ & $\begin{array}{c}24.10 \\
\mathrm{gh}\end{array}$ & $25.35 \mathrm{~d}$ & $26.41 \mathrm{c}$ & $\begin{array}{c}25.28 \\
\mathrm{bc}\end{array}$ \\
\hline $\begin{array}{l}\mathrm{CaCl}_{2}+\text { Glycerol with Wood } \\
\text { Shavings }\end{array}$ & $23.20 \mathrm{k}$ & $24.49 \mathrm{gh}$ & $25.67 \mathrm{~d}$ & $24.45 \mathrm{c}$ & $\begin{array}{l}24.10 \\
\text { gh }\end{array}$ & $\begin{array}{c}25.06 \\
\mathrm{de}\end{array}$ & $27.21 \mathrm{~b}$ & $\begin{array}{c}25.45 \\
\mathrm{~b}\end{array}$ \\
\hline AVG with Wood Shavings & $23.20 \mathrm{k}$ & $23.58 \mathrm{jk}$ & $24.41 \mathrm{gh}$ & $23.73 \mathrm{~d}$ & $\begin{array}{l}24.10 \\
\text { gh }\end{array}$ & $\begin{array}{l}24.52 \\
\text { efg }\end{array}$ & $24.21 \mathrm{~g}$ & $\begin{array}{c}24.28 \\
\mathrm{~d}\end{array}$ \\
\hline $\begin{array}{l}\text { Putrescine with Wood } \\
\text { Shavings }\end{array}$ & $23.20 \mathrm{k}$ & $23.94 \mathrm{ij}$ & $24.42 \mathrm{gh}$ & $23.85 \mathrm{~d}$ & $\begin{array}{l}24.10 \\
\text { gh }\end{array}$ & $23.50 \mathrm{~h}$ & $22.80 \mathrm{i}$ & $\begin{array}{c}23.46 \\
\mathrm{e}\end{array}$ \\
\hline $\begin{array}{l}\text { AVG followed by Putrescine } \\
\text { with Wood Shavings }\end{array}$ & $23.20 \mathrm{k}$ & $23.67 \mathrm{ij}$ & $24.61 \mathrm{fg}$ & $23.82 \mathrm{~d}$ & $\begin{array}{c}24.10 \\
\mathrm{gh}\end{array}$ & $\begin{array}{c}24.43 \\
\mathrm{fg}\end{array}$ & $\begin{array}{c}24.52 \\
\text { efg }\end{array}$ & $\begin{array}{c}24.39 \\
\mathrm{~d}\end{array}$ \\
\hline Means (D) & $23.20 \mathrm{c}$ & $24.45 \mathrm{~b}$ & $26.27 \mathrm{a}$ & & $\begin{array}{c}24.10 \\
\mathrm{c}\end{array}$ & $24.82 \mathrm{~b}$ & 25.96 a & \\
\hline
\end{tabular}


Table 6. Effect of postharvest applied treatments, cold storage time factor and their interaction on percentage of acidity of "Zaghloul" dates during 2017 and 2018 seasons

\begin{tabular}{|c|c|c|c|c|c|c|c|c|}
\hline \multirow{3}{*}{ Treatments $(\mathbf{T})^{*}$} & \multicolumn{8}{|c|}{ Storage Periods Days (D) } \\
\hline & \multicolumn{4}{|c|}{ Season 2017} & \multicolumn{4}{|c|}{ Season 2018} \\
\hline & $\mathbf{0}$ & 30 & $60 * *$ & $\begin{array}{c}\text { Means } \\
(\mathrm{T})\end{array}$ & $\mathbf{0}$ & 30 & 60 & $\begin{array}{c}\text { Means } \\
(\mathrm{T})\end{array}$ \\
\hline Control & $0.60 \mathrm{a}$ & $0.41 \mathrm{~g}$ & $0.33 \mathrm{i}$ & $0.44 \mathrm{e}$ & $0.56 \mathrm{a}$ & $0.51 \mathrm{bc}$ & $0.53 \mathrm{~b}$ & $0.53 \mathrm{a}$ \\
\hline Control with Wood Shavings & $0.60 \mathrm{a}$ & $0.51 \mathrm{c}$ & $0.38 \mathrm{~h}$ & $0.49 \mathrm{~d}$ & $0.56 \mathrm{a}$ & $0.48 \mathrm{de}$ & $0.44 \mathrm{f}$ & $0.49 \mathrm{~b}$ \\
\hline $\begin{array}{l}\text { Glycerol with Wood } \\
\text { Shavings }\end{array}$ & $0.60 \mathrm{a}$ & $0.52 \mathrm{bc}$ & $0.47 \mathrm{~d}$ & $0.532 \mathrm{a}$ & $0.56 \mathrm{a}$ & $0.50 \mathrm{~cd}$ & $0.41 \mathrm{~g}$ & $0.49 \mathrm{~b}$ \\
\hline $\mathrm{CaCl}_{2}$ with Wood Shavings & $0.60 \mathrm{a}$ & $0.53 \mathrm{~b}$ & $0.46 \mathrm{e}$ & $\begin{array}{l}0.530 \\
\mathrm{ab}\end{array}$ & $0.56 \mathrm{a}$ & $0.48 \mathrm{e}$ & $0.40 \mathrm{gh}$ & $0.48 \mathrm{c}$ \\
\hline $\begin{array}{l}\mathrm{CaCl}_{2}+\text { Glycerol with Wood } \\
\text { Shavings }\end{array}$ & $0.60 \mathrm{a}$ & $0.48 \mathrm{~d}$ & $0.43 \mathrm{f}$ & $0.50 \mathrm{~d}$ & $0.56 \mathrm{a}$ & $\begin{array}{l}0.50 \\
\text { cde }\end{array}$ & $0.37 \mathrm{i}$ & $0.47 \mathrm{c}$ \\
\hline AVG with Wood Shavings & $0.60 \mathrm{a}$ & $0.53 \mathrm{~b}$ & $0.45 \mathrm{e}$ & $0.52 \mathrm{~b}$ & $0.56 \mathrm{a}$ & $0.44 \mathrm{f}$ & $0.37 \mathrm{i}$ & $0.45 \mathrm{~d}$ \\
\hline $\begin{array}{l}\text { Putrescine with Wood } \\
\text { Shavings }\end{array}$ & $0.60 \mathrm{a}$ & $0.51 \mathrm{c}$ & $0.48 \mathrm{~d}$ & $0.53 \mathrm{ab}$ & $0.56 \mathrm{a}$ & $0.38 \mathrm{hi}$ & $0.32 \mathrm{j}$ & $0.42 \mathrm{e}$ \\
\hline $\begin{array}{l}\text { AVG followed by Putrescine } \\
\text { with Wood Shavings }\end{array}$ & $0.60 \mathrm{a}$ & $0.52 \mathrm{bc}$ & $0.43 \mathrm{f}$ & $0.51 \mathrm{c}$ & $0.56 \mathrm{a}$ & $0.36 \mathrm{i}$ & $0.33 \mathrm{j}$ & $0.42 \mathrm{e}$ \\
\hline Means (D) & 0.60 & 0.50 & 0.43 & & 0.56 & 0.46 & 0.39 & \\
\hline veans (D) & $\mathrm{a}$ & $\mathrm{b}$ & $\mathrm{c}$ & & $\mathrm{a}$ & $\mathrm{b}$ & $\mathrm{c}$ & \\
\hline
\end{tabular}

* Values within a column, with similar letters were not significantly different according to the Least Significant Difference (LSD) at 0.05 level.

** Values under the time factor $(0,30,60$ days) with similar letters according to the Least Significant Difference (LSD) at 0.05 level were not significantly different.

Table 7. Effect of postharvest applied treatments, cold storage time factor and their interaction on percentage of total sugars of "Zaghloul" dates during 2017 and 2018 seasons

\begin{tabular}{|c|c|c|c|c|c|c|c|c|}
\hline \multirow{3}{*}{ Treatments $(\mathbf{T})^{*}$} & \multicolumn{8}{|c|}{ Storage Periods Days (D) } \\
\hline & \multicolumn{4}{|c|}{ Season 2017} & \multicolumn{4}{|c|}{ Season 2018} \\
\hline & $\mathbf{0}$ & 30 & $60 * *$ & $\begin{array}{c}\text { Means } \\
(\mathbf{T})\end{array}$ & $\mathbf{0}$ & 30 & 60 & $\begin{array}{c}\text { Means } \\
(\mathbf{T})\end{array}$ \\
\hline Control & $23.40 \mathrm{j}$ & $29.17 \mathrm{e}$ & $31.29 \mathrm{~b}$ & $27.95 \mathrm{a}$ & $23.75 \mathrm{k}$ & $\begin{array}{c}26.01 \\
\text { hi }\end{array}$ & $30.58 \mathrm{c}$ & $\begin{array}{c}26.78 \\
\text { bc }\end{array}$ \\
\hline Control with Wood Shavings & $23.40 \mathrm{j}$ & $\begin{array}{c}26.79 \\
\text { gh }\end{array}$ & $30.64 \mathrm{c}$ & $26.94 \mathrm{c}$ & $23.75 \mathrm{k}$ & $\begin{array}{l}25.29 \\
\mathrm{ij}\end{array}$ & $\begin{array}{c}30.86 \\
\text { bc }\end{array}$ & $26.63 \mathrm{c}$ \\
\hline $\begin{array}{l}\text { Glycerol with } \quad \text { Wood } \\
\text { Shavings }\end{array}$ & $23.40 \mathrm{j}$ & $27.18 \mathrm{~g}$ & $29.92 \mathrm{~d}$ & $26.83 \mathrm{c}$ & $23.75 \mathrm{k}$ & $\begin{array}{c}26.58 \\
\mathrm{gh}\end{array}$ & $28.40 \mathrm{e}$ & $\begin{array}{c}26.43 \\
\mathrm{~cd}\end{array}$ \\
\hline $\mathrm{CaCl}_{2}$ with Wood Shavings & $23.40 \mathrm{j}$ & $28.57 \mathrm{f}$ & $32.72 \mathrm{a}$ & $28.12 \mathrm{a}$ & $23.75 \mathrm{k}$ & $\begin{array}{l}27.34 \\
f g\end{array}$ & $31.80 \mathrm{a}$ & $27.63 \mathrm{a}$ \\
\hline $\begin{array}{l}\mathrm{CaCl}_{2}+\text { Glycerol with Wood } \\
\text { Shavings }\end{array}$ & $23.40 \mathrm{j}$ & $28.36 \mathrm{f}$ & $\begin{array}{c}31.04 \\
\text { bc }\end{array}$ & $27.60 \mathrm{~b}$ & $23.75 \mathrm{k}$ & $\begin{array}{l}26.68 \\
\text { fgh }\end{array}$ & $\begin{array}{c}30.80 \\
\text { bc }\end{array}$ & $27.07 \mathrm{~b}$ \\
\hline AVG with Wood Shavings & $23.40 \mathrm{j}$ & $26.43 \mathrm{~h}$ & $28.28 \mathrm{f}$ & $26.04 \mathrm{~d}$ & $23.75 \mathrm{k}$ & $\begin{array}{l}25.40 \\
\mathrm{ij}\end{array}$ & $29.50 \mathrm{~d}$ & $26.21 \mathrm{~d}$ \\
\hline $\begin{array}{l}\text { Putrescine with Wood } \\
\text { Shavings }\end{array}$ & $23.40 \mathrm{j}$ & $25.90 \mathrm{i}$ & $28.16 \mathrm{f}$ & $25.82 \mathrm{e}$ & $23.75 \mathrm{k}$ & $24.94 \mathrm{j}$ & $28.40 \mathrm{e}$ & $25.69 \mathrm{e}$ \\
\hline $\begin{array}{l}\text { AVG followed by Putrescine } \\
\text { with Wood Shavings }\end{array}$ & $23.40 \mathrm{j}$ & $26.50 \mathrm{~h}$ & $28.45 \mathrm{f}$ & $26.15 \mathrm{~d}$ & $23.75 \mathrm{k}$ & $27.37 \mathrm{f}$ & $\begin{array}{c}31.51 \\
\mathrm{ab}\end{array}$ & $27.54 \mathrm{a}$ \\
\hline Means (D) & $\begin{array}{c}23.40 \\
\mathrm{c}\end{array}$ & $\begin{array}{c}27.32 \\
b\end{array}$ & $\begin{array}{c}30.06 \\
\mathrm{a}\end{array}$ & & $\begin{array}{c}23.75 \\
\mathrm{c}\end{array}$ & $26.20 \mathrm{~b}$ & $\begin{array}{c}30.30 \\
\mathrm{a}\end{array}$ & \\
\hline
\end{tabular}


Table 8. Effect of postharvest applied treatments, cold storage time factor and their interaction on anthocyanin content of "Zaghloul" dates during 2017 and 2018 seasons

\begin{tabular}{|c|c|c|c|c|c|c|c|c|c|}
\hline \multirow{3}{*}{\multicolumn{2}{|c|}{ Treatments $(\mathbf{T})^{*}$}} & \multicolumn{8}{|c|}{ Storage Periods Days (D) } \\
\hline & & \multicolumn{4}{|c|}{ Season 2017} & \multicolumn{4}{|c|}{ Season 2018} \\
\hline & & $\mathbf{0}$ & 30 & $60 * *$ & $\begin{array}{c}\text { Means } \\
(\mathbf{T})\end{array}$ & $\mathbf{0}$ & 30 & 60 & $\begin{array}{c}\text { Means } \\
(\mathbf{T})\end{array}$ \\
\hline Control & & $\begin{array}{l}22.35 \\
\text { fg }\end{array}$ & $19.30 \mathrm{i}$ & $19.43 \mathrm{i}$ & $20.36 \mathrm{~d}$ & $21.65 \mathrm{~g}$ & $20.48 \mathrm{~h}$ & $18.98 \mathrm{i}$ & $20.37 \mathrm{f}$ \\
\hline $\begin{array}{l}\text { Control with } \\
\text { Shavings }\end{array}$ & Wood & $\begin{array}{l}22.35 \\
\mathrm{fg}\end{array}$ & $\begin{array}{l}22.32 \\
\mathrm{fg}\end{array}$ & $\begin{array}{l}22.47 \\
\text { efg }\end{array}$ & $22.38 \mathrm{c}$ & $21.65 \mathrm{~g}$ & $\begin{array}{l}22.63 \\
\text { cde }\end{array}$ & $\begin{array}{c}22.73 \\
\mathrm{~cd}\end{array}$ & $22.34 \mathrm{c}$ \\
\hline $\begin{array}{l}\text { Glycerol with } \\
\text { Shavings }\end{array}$ & Wood & $\begin{array}{l}22.35 \\
\mathrm{fg}\end{array}$ & $\begin{array}{l}23.15 \\
\mathrm{bc}\end{array}$ & $\begin{array}{l}22.79 \\
\text { cde }\end{array}$ & $22.76 \mathrm{~b}$ & $21.65 \mathrm{~g}$ & $23.18 \mathrm{c}$ & $24.41 \mathrm{~b}$ & $\begin{array}{l}23.08 \\
a b\end{array}$ \\
\hline \multicolumn{2}{|c|}{$\mathrm{CaCl}_{2}$ with Wood Shavings } & $\begin{array}{l}22.35 \\
\mathrm{fg}\end{array}$ & $24.17 \mathrm{a}$ & $21.36 \mathrm{~h}$ & $\begin{array}{c}22.62 \\
\mathrm{bc}\end{array}$ & $21.65 \mathrm{~g}$ & $\begin{array}{l}22.27 \\
\text { defg }\end{array}$ & $20.61 \mathrm{~h}$ & $21.51 \mathrm{e}$ \\
\hline \multicolumn{2}{|c|}{$\begin{array}{l}\mathrm{CaCl}_{2}+\text { Glycerol with Wood } \\
\text { Shavings }\end{array}$} & $\begin{array}{l}22.35 \\
\mathrm{fg}\end{array}$ & $23.99 \mathrm{a}$ & $23.38 \mathrm{~b}$ & $23.24 \mathrm{a}$ & $21.65 \mathrm{~g}$ & $\begin{array}{l}22.49 \\
\text { cdef }\end{array}$ & $\begin{array}{c}22.04 \\
\text { defg }\end{array}$ & $\begin{array}{l}22.06 \\
\mathrm{~cd}\end{array}$ \\
\hline \multicolumn{2}{|c|}{ AVG with Wood Shavings } & $\begin{array}{l}22.35 \\
\mathrm{fg}\end{array}$ & $\begin{array}{l}22.60 \\
\text { def }\end{array}$ & $22.17 \mathrm{~g}$ & $22.37 \mathrm{c}$ & $21.65 \mathrm{~g}$ & $\begin{array}{l}21.94 \\
\text { efg }\end{array}$ & $\begin{array}{c}21.75 \\
\text { fg }\end{array}$ & $\begin{array}{c}21.78 \\
\text { de }\end{array}$ \\
\hline $\begin{array}{l}\text { Putrescine with } \\
\text { Shavings }\end{array}$ & Wood & $\begin{array}{l}22.35 \\
\mathrm{fg}\end{array}$ & $\begin{array}{l}22.63 \\
\text { def }\end{array}$ & $\begin{array}{c}23.01 \\
\text { bcd }\end{array}$ & $\begin{array}{c}22.66 \\
\text { bc }\end{array}$ & $21.65 \mathrm{~g}$ & $\begin{array}{l}22.60 \\
\text { cde }\end{array}$ & $24.32 \mathrm{~b}$ & $22.86 \mathrm{~b}$ \\
\hline \multicolumn{2}{|c|}{$\begin{array}{l}\text { AVG followed by Putrescine } \\
\text { with Wood Shavings }\end{array}$} & $\begin{array}{l}22.35 \\
\text { fg }\end{array}$ & $\begin{array}{c}23.14 \\
b c\end{array}$ & $\begin{array}{l}22.46 \\
\text { efg }\end{array}$ & $\begin{array}{c}22.65 \\
\mathrm{bc}\end{array}$ & $21.65 \mathrm{~g}$ & $23.11 \mathrm{c}$ & $25.21 \mathrm{a}$ & $23.32 \mathrm{a}$ \\
\hline \multicolumn{2}{|c|}{ Means (D) } & $22.35 \mathrm{~b}$ & $\begin{array}{c}22.66 \\
\mathrm{a}\end{array}$ & $\begin{array}{c}22.13 \\
\mathrm{c}\end{array}$ & & $\begin{array}{c}21.65 \\
b\end{array}$ & $\begin{array}{c}22.34 \\
\mathrm{a}\end{array}$ & $\begin{array}{c}22.51 \\
\mathrm{a}\end{array}$ & \\
\hline
\end{tabular}

* Values within a column, with similar letters were not significantly different according to the Least Significant Difference (LSD) at 0.05 level.

** Values under the time factor $(0,30,60$ days) with similar letters according to the Least Significant Difference (LSD) at 0.05 level were not significantly different.

\section{REFERENCES}

Ait-Oubahou, A. and Yahia, E. M. (1999). Postharvest handling of dates. Postharvest News and Information, 10(6), 67N-74N.

Association of Official Agricultural Chemists. (1995). Official Methods of Analysis of A. O. A. C. Published by A.O.A.C. Chap., (4): p.18-20;(37) p.10 virginia22201=3301(U.S.A.).

Atia, A.; Abdelkarim, D.; Younis, M. and Alhamdan, A. (2018). Effects of calcium chloride and salicylic acid postharvest treatments on the quality of khalal Barhi dates at different ripening levels during cold storage. J. Food Measurement and Characterization, 12(2), 1156-1166.

Bregoli, A. M.; Scaramagli, S.; Costa, G.; Sabatini, E.; Ziosi, V.; Biondi, S. and Torrigiani, P. (2002). Peach (Prunus persica L.) fruit ripening: aminoethoxyvinylglycine (AVG) and exogenous polyamines effect on ethylene emission and flesh firmness. Physiol. Plant., 114: 472-481.

Chao, C. T. and Krueger, R. R. (2007). The date palm (Phoenix dactylifera L.): overview of biology, uses, and cultivation. HortScience, 42(5): 1077-1082.

Clayton, M.; Biasi, W. V.; Southwick, S. M. and Mitcham, E. J. (2000). ReTain affects maturity and ripening of "Bartlett" pear. HortScience, 35(7): 1294-1299.

Costa, G.; Bregoli, A. M.; Noferini, M.; Ziosi, V.; Biondi, S. and Torrigiani, P. (2003). A pluriennial experience in controlling peach ripening using different natural substances. Plant Growth Regulation Society of America, August, 3-6.2:15.

Costat (2008). Costat version 6.400, CoHort Software 798 Lighthouse Ave. PMB 320 Monterey, CA, 93940, USA.

El-Sharony, T. F.; Amin, O. A. and AbdAllah, A. S. (2015). Effect of some postharvest treatments on quality and storability of date palm fruits Zaghloul and Samany Cultivars. The Intern. J. Environ. Sci., 283(1774): 1-21.

Faostat, F. A. O. (2017). Food and Agriculture Organization of the United Nations Statistics Division Internet site. Available online: http://www. fao. org/faostat/en/\# data.

Farag, K. M. (1998). Development to the rutab stage without accompanied fruit softening of 
Zaghloul dates by some postharvest treatments. In Proceedings of First International Conference on Date Palms, March (pp. 8-10).

Farag, K. M. (2016). Date palm, A Wealth of Healthy Food. Encyclopedia of Food and Health (FOHE). Chapter, 00215.

Farag, K. M. and Al-Masri, H. H. (1999). Extending the khelal stage of" khesab" dates using new method of packaging and modified calcium formation. Emirates J. Food Agric., 21-30.

Farag, K. M. and Kassem, H. A. (1998). Accelerating and intensifying color formation of "Zaghloul" date palm fruit using modified ethephon formations. Proceedings of the First International Meeting on Date Palm. United Arab Emirates Univ., Al- Ain, UAE. pp.62-71 .643 .

Farag, K. M.; Nagy, N. and Elnoam, S. M. (2017). Retardation of rutab development of "Zaghloul" dates and enhancing bunch ripening uniformity by preharvest application of calcium and the antiethylene Compound 1- methyl cyclopropene, 1- MCP.. J. Plant Produc., 8(9): 907-911.

Fuleki, T. and Francis, F. J. (1968). Quantitative methods for anthocyanins. 1Extraction and determination of total anthocyanin in cranberries. J. Food Sci., 33:7277 .

Hussein, M. A.; Mahmoud, H. M.; Ahmed Amin, K. I. and Mustafa, A. (1993 a). Physiological studies for prolonging khalal stage of Zaghloul dates during storage. A. Effect of preharvest application of calcium chloride. In Proc. 3rd Int. Symp. on the Date Palm, King Fasal Univ., Al-Hassa, Saudi Arab (pp. 445-458).
Hussein, M. A.; Mahmoud, H. M.; Ahmed Amin, K. I. and Mustafa, A. (1993 b). Physiological studies for prolonging khalal stage of Zaghloul dates during storage. C. Effect of postharvest applications of calcium chloride. In Proc. 3rd Int. Symp. on the Date Palm, King Fasal Univ., Al-Hassa, Saudi Arab (pp. 459-473).

Mitcham, B.; Clayton, M. and Biasi, B. (1998). ReTain delays maturity of Bartlett pears. Good Fruit Grower, 49: 33-35.

Omaima, M.H.; Maksoud, M.A.; Nagwa, S.Z. and Malaka, A.S. (2011). Use of preharvest treatments to keeping quality and long shelf life of some date palm cultivars. Selc , uk Tarım ve Gıda Bilimleri Dergisi 25: 6574.

Roy, S.; Conway, W. S.; Buta, J. G.; Watada, A. E., Sams, C. E. and Wergin, W. P. (1996). Surfactants affect calcium uptake from postharvest treatment of "Golden Delicious" apples. J. Amer. Soc. Hort. Sci., 121(6): 1179-1184.

Serrano, M.; Pretel, M. T.; Botella, M. A. and Amoros, A. (2001). Physicochemical changes during date ripening related to ethylene production. Food Sci. Technol. Intern., 7(1): 31-36.

Tavakoli, K. and Rahemi, M. (2014). Effect of polyamines, 2, 4-D, isopropyl ester and naphthalene acetamide on improving fruit yield and quality of date (Phoenix dactylifera L.). Intern. J. Hort. Sci. Technol., 1(2): 163169.

Zabar, A. and Borowy, A. (2012). Cultivation of date palm in Iraq. Annales Universitatis Mariae Curie-Skłodowska. Sectio EEE: Horticultura, 22(1): 39-54. 